\title{
Prostate Cancer cT2a TNM Finding v8
}

National Cancer Institute

\section{Source}

National Cancer Institute. Prostate Cancer CT 2a TNM Finding v8. NCI Thesaurus. Code C140135.

Prostate cancer in which the tumor involves one-half of one side or less. (from AJCC 8th Ed.) 